ECOLOGICA, Vol. 28, No 104 (2021), 591-596

https://doi.org/10.18485/ecologica.2021.28.104.14

Originalni naučni rad

UDC: 323.212:[616.98:578.834

\title{
Građanska nauka u uslovima COVID-19 pandemije
}

\section{Citizen science in the COVID-19 pandemic}

\author{
Jelena Banović ${ }^{*}$, Aleksandra Bradić-Martinović ${ }^{2}$, Nemanja Nedović ${ }^{3}$ \\ 1,2Institut ekonomskih nauka, Zmaj Jovina 12, Beograd, Srbija / \\ Institute of Economic Sciences, Zmaj Jovina 12, Belgrade, Serbia \\ ${ }^{3}$ Beogradska bankarska akademija, Zmaj Jovina 12, Beograd, Srbija / \\ Belgrade Banking Academy, Zmaj Jovina 12, Belgrade, Serbia \\ *Autor za prepisku / Corresponding author
}

Rad primljen / Received: 03.09.2021, Rad prihvaćen / Accepted: 11.10.2021.

Sažetak: Digitalizacija i razvoj informacionih i komunikacionih tehnologija omogućili su rapidno sprovođenje naučnih istraživanja, a veliki skupovi podataka su na dohvat ruke zainteresovanim stranama. Tehnološki i ekonomski razvoj, ekonomija zasnovana na znanju i loT utiču na kreiranje naučnih podataka, a kroz uticaj Interneta koji je prisutan u životu pojedinaca različitih uzrasta, postaje sve jasnije koliku moć poseduju informacione tehnologije. Mnogi teoretičari zbog toga smatraju da u društvu 21. veka alate informacionih tehnologija ne bi trebalo prepustiti samo velikim kompanijama, naučnim centrima i slično, već da pristup treba da bude omogućen i pojedincima. Omogućavanje građanima da postanu akteri u naučnim istraživanjima podrazumeva dobro informisane pojedince $u$ informacionom društvu, koji mogu biti kreatori, a ne samo konzumenti tehnologija i informacija. Pod terminom građanske nauke podrazumevaju se istraživanja koja su sproveli naučnici-amateri. $\mathrm{Na}$ ovaj način, dolazi se do potpune demokratizacije nauke i do potpunog povezivanja javnosti i naučne zajednice. Mogućnost za učešće građana u nauci je najbolje ispoljena tokom COVID-19 pandemije; istraživači su dobili priliku da prisnije sarađuju sa društvom i tako lakše dođu do neophodnih informacija i podataka, a pojam građanske nauke je postao naglašen u različitim kontekstima u kojima je partnerstvo između istraživača, građana, donosioca odluka i kreatora javnih politika prepoznat kao ključ uspeha za borbu protiv pandemije koja je zadesila čitav svet.

Ključne reči: istraživački podaci, građanska nauka, COVID-19.

\begin{abstract}
The development of ICT and digitization enables rapid conducting of scientific research, and big datasets are available to interested parts. Technological and economic development, knowledge-based economy and loT have an effect on the creation of scientific data, and through the influence of the Internet, it is becoming increasingly clear how powerful are information technologies. Many researchers consider that in 21 st-century society, information technologies tools should not be reserved only for big companies and scientific centres but access also should be provided to individuals as well. Enabling citizens to become participants in scientific research implies well-informed individuals in the information society, who can be creators and not only users of technology and information. The term "citizen science" refers to research conducted by amateur scientists. So, there is complete democratization of science and a connection between the citizen and the scientific community. The opportunity for citizen to participate in science was demonstrated during the COVID-19 pandemic; the opportunity was given to the researchers - to work more closely with society and to access more easily the necessary information and data. The concept of citizen science has become emphasized in various contexts in which partnerships between researchers, citizen, decisionmakers, and policymakers have been recognized as the key to success in the process of fighting the global pandemic.
\end{abstract}

Keywords: research data, citizen science, COVID-19.

\footnotetext{
10rcid.org/0000-0001-8089-0143, e-mail: jelena.banovic@ien.bg.ac.rs

2orcid.org/0000-0002-5930-9278, e-mail: abmartinovic@ien.bg.ac.rs

${ }^{3}$ orcid.org/0000-0003-1667-6462, e-mail: nemanja.nedovic@bba.edu.rs
} 


\section{UVOD / INTRODUCTION}

Digitalizacija i razvoj informacionih i komunikacionih tehnologija doveli su do toga da se istraživanja u nauci danas obavljaju brzo, uz velike skupove podataka koji su na dohvat ruke naučnoj zajednici. Tehnološki i ekonomski razvoj, ekonomija zasnovanje na znanju i loT, postaju deo svakodnevnog života. Kroz uticaj Interneta, koji je prisutan u životu pojedinaca različitih uzrasta, postaje sve jasnije koliku moć poseduju alati informacionih tehnologija. Svi korisni aspekti informacionih tehnologija ipak nisu do kraja iskorišćeni i ako se aktiviraju na pravilan način, mogu u velikoj meri ojačati naučnu zajednicu. Mnogi smatraju da u društvu 21. veka sve navedene alate ne bi trebalo prepustiti samo velikim kompanijama $i$, istraživačkim centrima, već da se pristup i korišćenje treba omogućiti i zainteresovanim pojedincima koji ne predstavljaju nužno deo istraživačke zajednice. Omogućavanje građanima da postanu akteri u generisanju podataka rezultira dobro informisanim pojedincima, koji mogu biti kreatori, a ne samo konzumenti tehnologija i informacija. Mogućnost građana da se bave informacionim tehnologijama kao alatima za otkrivanje i komunikaciju znanja postaje sve definisanija, posebno u periodu velike pandemije koja je zadesila čitav svet.

\section{DIGITALIZACIJA SAVREMENOG DRUŠTVA / DIGITIZATION OF MODERN SOCIETY}

Informacione i komunikacione tehnologije su danas daleko rasprostranjenije nego što su bile ranije, a Internet i digitalni uređaji su dostupni svim generacijama, čime se pokreće eksponencijalni rast globalnih podataka i informacija. Društva koja su na naprednim nivoima digitalizacije ostvaruju značajnu korist i napredak u socijalnim, ekonomskim, političkim i privrednim sektorima, te se sa sigurnošću može reći da su digitalne tehnologije i njihov napredak, istorijski posmatrano, jedan od najvećih i najbrže usvajanih fenomena savremenog društva. Korišćenje Interneta, potpomognuto upotrebnom pametnih uređaja, loT i drugih servisa, uslovili su cirkularno kruženje i neprekidnu razmenu podataka i informacija. Razvoj različitih alata koje je Industrijska revolucija 4.0 donela omogućavaju brzo prikupljanje velikog obima podataka koje su od koristi svima - predstavnicima naučne zajednice, donosiocima javnih politika, privrednim subjektima, ali i široj javnosti, građanima. Zemlje u razvoju masovno promovišu digitalnu transformaciju, a lideri u ovom procesu su svesni da je jedan od glavnih preduslova za ispunjenje ovog cilja zapravo sposobnost stanovništva da koriste tehnologije koje im se nude, odnosno da poseduju digitalne kompetencije i veštine
(Bradić-Matinović, Banović, 2018). Zbog toga, mnogi teoretičari smatraju da u društvu 21. veka dostupnu tehnologiju ne treba prepustiti isključivo velikim kompanijama i institucijama, već postaje nužnost da budu dostupne društvu, koje je, uz osnove poznavanja digitalnih sadržaja i posedovanja digitalnih kompetencija, dovoljno obučeno da tumači tehnološke aspekte, čime se postiže demokratizacija nauke. Omogućavanjem građanima da koriste tehnologiju dolazi se do sinergije između nauke i pojedinca, koja je u najvećem broju slučajeva vrlo produktivna. Informisane osobe, koje u informacionom društvu ne moraju biti isključivo potrošači novonastalih tehnologija, već i njeni direktni konzumenti, su glavna odlika građanske nauke, jer se dolazi do ekspeditivnijeg prikupljanja važnih podataka sa terena.

\section{GRAĐANSKA NAUKA / CITIZEN SCIENCE}

Termin građanska nauka (engl. Citizen science) nije u potpunosti ukorenjen u srpskom jeziku, pa se ovaj pristup nauci još naziva i nauka za građane, građani u nauci ili volonterska nauka. Termin definiše ideju povezivanja nauke i građana (stanovništva), odnosno njihovog uključivanja u određene faze naučnog procesa, uz obostranu korist. Kako navode Dickinson i ostali, građanska nauka uključuje „neprofesionalce“ u autentična naučna istraživanja, u različitim vremenskim segmentima - od dugogodišnjih velikih projekata, kao što je, na primer, Anketa o uzgajanju ptica, do više manjih istraživačkih iskustava (Dickinson et al., 2012). Građanska nauka obuhvata različite nivoe angažovanja - od bolje informisanosti o dešavanjima u nau$\mathrm{ci}$, do učešća u samom naučnom procesu kroz posmatranje, prikupljanje ili obradu podataka (European Commission, 2020). Kako navode Christine \& Thinyane, pojam građanske nauke se može posmatrati i sa stanovišta ljudskih prava, jer po Univerzalnoj deklaraciji o ljudskim pravima, prepoznaje se pravo svakog pojedinca "da učestvuje u naučnom napretku i da ubira njegovu korist" (Christine, Thinyane 2021). Ranije se ova vrsta angažovanja $u$ nauci vezivala isključivo za prirodne nauke, a u poslednje vreme, uz prepoznavanje koristi učešća građana u istraživanjima, od velike je pomoći i u društvenim i tehničkim naukama.

Istorijski gledano, možemo reći da građanska nauka datira iz vremena kada su naučnici počeli da se bave prvim naučnim istraživanjima. Kako navode Smederevac i ostali, ovaj termin se povezuje i sa terminom gentleman scientist, što podrazumeva pojedinca koji sam finansira svoja istraživanja, poput Čarlsa Darvina ili Nikole Tesle (Smederevac i dr, 2020). Ipak, do udruživanja nauke i građanske nau- 
ke nije došlo odmah, a nedavna istraživanja pokazuju da su podaci koji su prikupljeni u okviru građanske nauke, jednako pouzdani kao oni koje prikupljaju naučnici. Analiza je pokazala da su se podaci koje su prikupljali građani i oni koje su prikupljali naučnici poklopili u 96\% slučajeva (Samuel, 2021).

Demokratizacija nauke i suočavanje sa globalnim izazovima uslovljavaju težnju ka pronalasku efikasnih načina kako da se dodatno zaštite ugrožene vrste biljaka i životinja, kako da se utiče na smanjenje zagađenosti vazduha, spreče bolesti ili ubrzaju medicinska istraživanja. Nauci 21. veka je potrebno sve više resursa, te su joj od velike važnosti svi zainteresovani pojedinci koji dobrovoljno učestvuju u nadgledanju kvaliteta vode i vazduha ili procesima za unapređenje medicinskih istraživanja i slično. Četiri osnovna obeležja građanske naučne prakse su (SciStarter, 2020):

- Svako može da učestvuje;

- Učesnici kombinuju iste protokole kao i naučnici kako bi podaci imali najviši kvalitet i kako bi mogli neometano da se koriste;

- Podaci mogu da pomognu naučnicima da dođu do važnih zaključaka;

- Akademska zajednica i učesnici građanske nauke rade zajedno i dele podatke javno kako bi im svi imali pristup.

$\mathrm{U}$ tabeli 1 su predstavljeni oblici građanskog angažovanja i njihova interakcija sa akademskom zajednicom.

Tabela 1. Modeli građanskog angažovanja

Table 1. Models of citizens engagement

\begin{tabular}{|l|l|}
\hline \multicolumn{1}{|c|}{ Model } & \multicolumn{1}{|c|}{ Interakcija između profesionalnih istraživača I građana } \\
\hline Ugovoreni model & $\begin{array}{l}\text { Zajednica ima zahtev prema istraživačima da se određeno } \\
\text { istraživanje sprovede i da se izveštaj o rezultatima predstavi javno }\end{array}$ \\
\hline Model doprinosa & $\begin{array}{l}\text { Projekte uglavnom osmišljavaju naučnici, a zajednica im doprinosi } \\
\text { kroz prikupljanje podataka }\end{array}$ \\
\hline Model saradnje & $\begin{array}{l}\text { Projekte uglavnom osmišljavaju naučnici, a zajednica im doprinosi } \\
\text { kroz prikupljanje podataka, ali takođe doprinosi u usavršavanju } \\
\text { projekta i analizi podataka }\end{array}$ \\
\hline Zajednički osmišljen model & $\begin{array}{l}\text { Projekte osmišljavaju naučnici i članovi zajednice i rade zajedno i } \\
\text { najveći deo njih je aktivno uključen u većinu ili sve procese u toku } \\
\text { istraživanja }\end{array}$ \\
\hline Kolegijalni model & $\begin{array}{l}\text { Pojedinci sprovode istraživanje nezavisno, a na akademskoj zajednici } \\
\text { je da li će ih uvažiti kao relevantne. }\end{array}$ \\
\hline
\end{tabular}

Izvor / Source: Christine D.I., Thinyane M. (2021)

U zavisnosti od ličnih interesa i znanja, građani sami odlučuju oblast u koju će se uključiti posmatranje ptica, identifikovanje galaksija ili biljnih vrsta, učešće u testiranju nuspojava medikamenata i slično. Prema Evropskoj komisiji, neke od prednosti ovog koncepta su:

- Efikasno i transparentno korišćenje javnog i privatnog finansiranja nauke i istraživanja;

- Bolji angažman u istraživanju, upravljanju i raspodeli odgovornosti;

- Približavanje kreiranja politika građanima, zasnivajući ih na naučnim dokazima (European Commission, 2020).

Građanska nauka ima svoj udeo u skoro svim naučnim oblastima - ekologiji, astronomiji, statistici, medicini, ekonomiji. Ogromna saradnja koja se ostvaruje na globalnom nivou, u dugom vremenskom periodu dovodi do otkrića za koja se smatra da ih jedan naučnik sam ne bi mogao postići za mnogo duži vremenski period.

Učesnici u procesu građanske nauke nisu profesionalci. To su najčešće pojedinci koji sarađuju s naučnicima iz akademskih krugova na načine koji unapređuju naučni rad. Uključuju se osobe različitih životnih doba i obrazovanja, a šansa da postoji jedno naučno istraživanje s tematikom koja nekom pojedincu predstavlja hobi ili zanimanje je u današnje vreme jako velika. Kako su u prošlosti prikupljanja i analize velikih uzoraka podataka bila dugotrajna i često izuzetno skupa, građanska nauka ima mogućnost da ovo prevaziđe. Veliki broj pojedinaca iz celog sveta može da doprinese radu, kroz prijavljivanje ili analizu podataka koju su uočili u određenom vremenskom intervalu ili na posmatranom uzorku. Količina podataka koja se na takav način prikuplja, obuhvatajući različite zone posmatranja i izučavanja u različitim vremenskim intervalima, potpada pod kategoriju Big Data (Veliki podaci), koji su 
od velike važnosti za naučnu, ali i širu društvenu zajednicu.

Prethodnih godina, formirane su brojne platforme za angažovanje građana u posmatranju $\mathrm{i}$ istraživanju različitih ekoloških, bioloških ili društvenih fenomena. Na primer, jedna od njih je i NatureWatch, kanadska platforma gde se mogu pronaći objedinjeni podaci koje dostavljaju građani širom Kanade, a koriste in istraživači sa nekoliko prestižnih kanadskih univerziteta, kako bi se proširilo znanje o promenama u biodiverzitetu, klimi ili prirodnom okruženju (Nature Watch, 2021). Uz pomoć veb lokacije, na pametnim telefonima se mogu pratiti flora i fauna u određenom području. Prikupljeni podaci su kasnije javno dostupni preko platforme, uz poštovanje osnovnih postulata Otvorene nauke i Otvorenih podataka, mogu se koristiti kao dragocen izvor informacija i potpora u nekim daljim istraživanjima (Nature Watch, 2021).

\section{GRAĐANSKA NAUKA U KONTEKSTU PANDEMIJE COVID-19 / CITIZEN SCIENCE IN THE COVID-19 CONTEXT}

Pandemija COVID-19 koja je od proleća 2020. zadesila čitav svet zatekla je nespremne sve sfere društva. Pokušaji prilagođavanja novonastalim promenama zahtevali su od samog početka da nauka i društvo rade zajedno, kako bi se pravovremeno podelile informacije, resursi i primenila trenutna rešenja. U kontekstu globalne krize, građanska nauka nudi priliku za transformaciju društva kroz njegovo angažovanje u prikupljanju podataka i informacija "sa terena", kao pomoć u tradicionalnim procesima donošenja odluka. Jedan od najvećih izazova u pandemiji bila je nemogućnost da se efikasno prati virus i kretanje populacije kako bi se sprečilo rapidno širenje bolesti, kao i nemogućnost nastavka velikih istraživanja iz različitih naučnih oblasti, zbog nemogućnosti kretanja pojedinaca usled karantina. Istraživački timovi, koje su često do tog momenta činili isključivo istraživači iz istih ili sličnih oblasti, sada se otvaraju za građane, čime se mogućnost integrisanja različitih perspektiva, iskustava i znanja dešava rapidno, a sve u cilju razmene informacija i boljeg razumevanja novonastale situacije.

Pandemija je dovela do velikog povećanja učešća građana u nauci, gde ljudi bez specijalizovane obuke prikupljaju podatke širom sveta ili vrše analize podataka na Internetu kako bi pomogli naučnicima. Jako veliki broj amatera širom sveta je, na zahtev institucionalnih istraživača, prikupljalo informacije o najrazličitijim fenomenima - od posmatranja ugroženih vrsta flore i faune, praćenja mentalnog zdravlja stanovništva usled pandemije, do praćenja šire- nja virusa. Kako se ne bi izgubio kontinuitet u radu i pribavljanju važnih podataka za nauku, građani su se masovno uključivali u različite projekte.

Uprkos tome što je pandemija zaustavila svet na određeno vreme, brojna istraživanja na terenu su sprovedena uz pomoć građanske nauke. Kao rezultat toga, pojedine platforme na kojima građani mogu da dele svoje podatke i zapažanja, a koje se bave životnom sredinom u Americi, zabeležile su značajan porast u izveštavanju, za čak $29 \%$ u odnosu na prethodnu godinu (National Geographic Report, 2021).

Međutim, u vreme pandemije, osnovane su $\mathrm{i}$ brojne aplikacije i nove platforme kako bi građani pomogli u prikupljanju neophodnih informacija o bolesti i njenim uticajima na okruženje. CoronaReport je projekat građanske nauke, koji demokratizuje izveštavanje o koronavirusu i čini izveštaje dostupnim ostalim građanima. Pojedinci su imali mogućnost da izveštavaju o svojim iskustvima u doba pandemije, uključujući i činjenicu kako virus utiče na područje u kome žive i kako funkcioniše njihova zajednica. Izveštavanje se vrši preko mobilne aplikacije koja je dostupna za mobilne telefone, a razvio ju je Univerzitet u Edinburgu (CoronaReport, 2021). Za ovakvu vrstu izveštavanja, neophodno je da pojedinac poseduje osnovne digitalne veštine, a podaci su bili od velike koristi u naučnim istraživanjima koja su se ticala mobilnosti stanovništva, psiholoških uticaja bolesti na pojedince u zajednici i slično. Na sledećoj mapi (Slika 1), prikazan je raspored građana prema državama iz koje se angažuju da na dnevnom ili nedeljnom nivou izveštavaju o svojim zapažanjima u doba pandemije.

Platforma Flusurvey je kreirana 2009. godine od strane Agencije za javno zdravlje Engleske, za praćenje širenja svinjskog gripa. Danas se građani Engleske mogu registrovati na ovoj platformi kako bi prijavili potencijalne simptome koje imaju usled zaražavanja Covidom, a nadležni sve informacije mogu da koriste u cilju praćenja i transformacije virusa u zajednici. Kako se navodi, u ovom trenutku preko 8000 građana aktivno beleži simptome koje ima kao i transmisiju virusa, a podaci su od velikog značaja naučnoj zajednici (Flusurvey, 2021). Brojna istraživanja iz različitih naučnih oblasti u vreme pandemije urađena su upravo uz pomoć građana. Tako je istraživanje koje je sprovedeno na teritoriji Srbije, a tiče se svakodnevnog praćenja emocionalnih odgovora i reakcija na pandemiju COVID-9 urađeno na osnovu podataka koje su individue iz društva priložili kao svoja lična zapažanja (Sadiković i dr. 2020). 


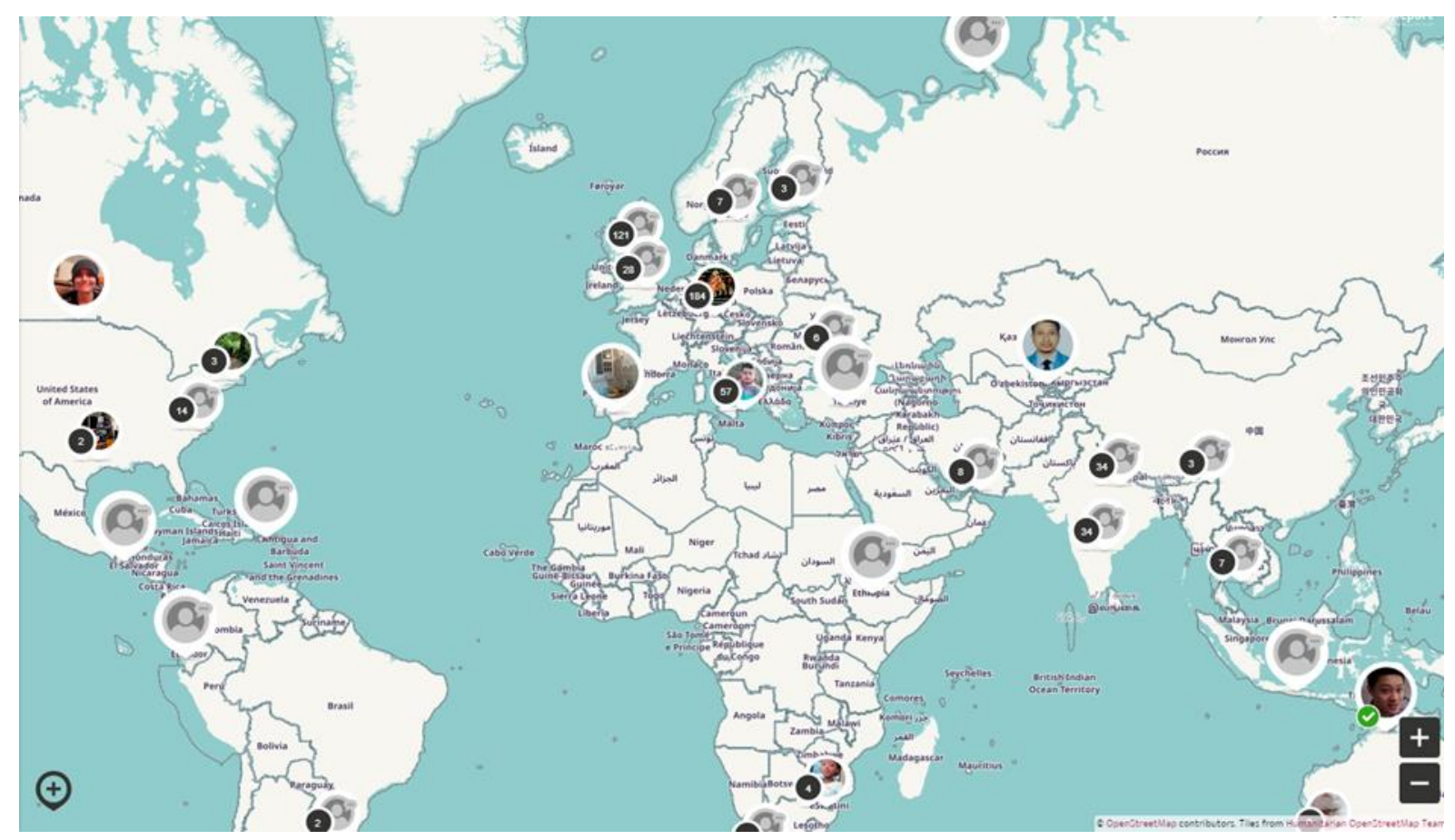

Slika 1. Prikaz građana iz različitih država koji na dnevnom/nedeljnom nivou izveštavaju o situacijama u doba pandemije COVID-19

Figure 1. Review of citizens from different countries who gives a report on daily/weekly basis about situation with COVID-19 Izvor / Source: https://www.coronareport.global/faq

\section{ZAKLJUČAK / CONCLUSION}

Digitalizacija je omogućila globalno uključivanje građana u naučna istraživanja, gradeći koncept "građanske nauke“. Istraživanja najčešće podrazumevaju posmatranja i merenje parametara životne sredine i okruženja, kao što su kvalitet vode, biodiverzitet i slično, ali i praćenje širenja bolesti, u situaciji čiji smo svedoci tokom poslednjih godinu dana. Uprkos očekivanjima, zainteresovanost građana da prikupljaju i analiziraju vredne istraživačke podatke nije opala ni za vreme COVID-19 pandemije, kada je kretanje bilo onemogućeno, a statistike potvrđuju da je angažovanje u nekim aspektima i povećano. Platforme koje su namenski kreiranje za praćenje širenja virusa, simptoma i drugih uticaja virusa na životnu sredinu i zajednicu su sve više prisutne, a koristi angažovanja građana u nauci će biti još vidljiviji u narednom periodu, kada se budu sanirale ekološke, ekonomske i posledice po javno zdravlje. Republika Srbija bi trebala da podigne svest $u$ pogledu mogućnost razvoja građanske nauke, po ugledu na razvijene zemlje.

\section{Zahvalnica / Acknowledgement}

Izrada ovog rada je podržana od strane Ministarstva prosvete, nauke i tehnološkog razvoja Republike Srbije.

\section{LITERATURA / REFERENCES}

[1] Bradić-Martinović, A., Banović, J. (2018). Assessment of Digital Skills in Serbia with Focus on Gender Gap. Journal of Women's Entrepreneurship and Education. No. 1-2, 54-67.

[2] Christine, D.I., Thinyane, M. (2021). Citizen science as a data-based practice: A consideration of data justice, Patterns, 2(4), 100224.

[3] CoronaReport (2021). https://www.coronareport. global/faq. Pristupljeno: 10.4.2021.

[4] Dickinson, J. L., Shirk, J., Bonter, D., Bonney, R., Crain, R.L., Martin, J., Phillips, T., Purcell, K. (2012). The current state of citizen science as a tool for ecological research and public engagement. Frontiers in Ecology and the Environment. 10(6), 291-297.

[5] European Commission. (2020). Citizen ScienceShaping Europe's digital future,

https://ec.europa.eu/digital-single-market/en/ citizen-science. Pristupljeno: 1.4.2021.

[6] Flusurvey (2021). https://flusurvey.net/ Pristupljeno: 8.4.2021.

[7] National Geographic Report. (2021). https://www. nationalgeographic.com/animals/article/citizenscience-increasing-pandemic-insects. Pristupljeno: 6.4.2021. 
[8] NatureWatch. (2021). https://www.naturewatch. ca/about/ . Pristupljeno: 6.4.2021.

[9] Sadiković, S., Branovački, B., Oljača, M., Mitrović, D., Pajić, D., Smederevac, S. (2020). Daily Monitoring of Emotional Responses to the Coronavirus Pandemic in Serbia: A Citizen Science Approach. Frontiers in Psychology. Vol. 11, doi: 10.3389/ fpsyg.2020.02133.

[10] Samuel, S. (2021). Citizen science is booming during the pandemic, https://www.vox.com/ future-perfect/22177247/citizen-scienceamateur-backyard-birding-astronomy-covidpandemic. Pristupljeno: 3.4.2021.

[11] Scistarter. (2020). Introduction to Citizen Science. https://scistarter.org/citizen-science. Pristupljeno: 3.4.2021.

[12] Smederevac, S., Pajić, D., Radovanović, S., Ghilezan, S., Čolović, P., Milosavljević, B. (2020). Otvorena nauka - praksa i perspektive. Univerzitet u Novom Sadu, Novi Sad. 